\title{
Smart Tourism: Concepts and Insights from Central Europe
}

\section{Tomáš Gajdošík}

e-mail: tomas.gajdosik@umb.sk

Department of Tourism and Hospitality, Faculty of Economics,

\author{
Matej Bel University, Banská Bystrica, Slovakia
}

Gajdošík, T. (2018). Smart Tourism: Concepts and Insights from Central Europe. Czech Journal of Tourism, 7(1), 25-44.

DOI: 10.1515/cjot-2018-0002.

\begin{abstract}
Nowadays, tourism sector needs to adapt to a very fast changing environment and stronger competitiveness. Smart tourism describes the current stage of tourism development influenced by the evolution of information technologies and is becoming a promising way how to face the new market conditions. The aim of the paper is to review the conceptual foundations of smart tourism and to analyse the development of smart tourism initiative in Central Europe, specifically in Slovakia. The paper adopts an exploratory multiple case study methodology, focusing on information technologies used by Central European tourists, willingness of data sharing and the use of the state-of-the-art technologies in tourism businesses. Moreover, the smart concept is examined based on the $(\mathrm{SA})^{6}$ framework in three tourism destinations. The paper concludes that smart tourism should not be the ultimate goal, but with the help of technology, innovation, and cooperation, it should bring better tourist experience, wellbeing of residents, enhance effectiveness and competitiveness of businesses and destinations, and lead to overall competitive sustainability.
\end{abstract}

\section{Keywords}

information technologies, smart business, smart destination, smart tourist

JEL classification: L83, M15 


\section{Introduction}

The word 'smart' has become a buzz word not only in the academic sphere, but also in the praxis. Almost everything is becoming smart. People use smartphones, construct smart buildings, live in smart homes with smart TVs, smart fridges or smart heating. The smart concept has emerged as a result of the rise of information technology and the need for sustainability. It is mainly based on information technologies that integrate hardware, software and network technologies to provide real-time awareness of the real world and advanced analytics to help people make more intelligent decisions about alternatives, as well as actions that will optimize business processes and business performances (Washburn et al., 2010). These technologies trigger innovation and leads to higher competitiveness, while ensuring sustainable development (Aina, 2017). As tourism is highly dependent on information technologies (e.g., Benckendorff, Sheldon, \& Fesenmaier, 2014; Buhalis, 2003) and in the last years these technologies have been so tightly knitted into the fabric of the travel experience and management of tourism product (Xiang, Tussyadiah, \& Buhalis, 2015), the smart phenomenon has also penetrated into the tourism sector.

Smart tourism describes the current stage of tourism development influenced by the evolution of information technologies. As Gretzel (2011) points out, smart tourism is a step in the evolution of information technologies in tourism in which the physical and governance dimensions of tourism are entering the digital playing field and new levels of intelligence are achieved. It is tourism supported by integrated efforts at a destination to collect and aggregate/ harness data derived from physical infrastructure social connections, government/ organizational sources, and human bodies/ minds in combination with the use of advanced technologies to transform that data into on-site experiences and business value propositions with a clear focus on efficiency, sustainability, and experience enrichment (Gretzel, Sigala, Xiang, \& Koo, 2015).

Smart tourism can be seen as a direct extension of e-tourism. E-tourism donates the analysis, design, implementation and application of information technologies/ e-commerce solutions in the travel and tourism sector, as well as the analysis of the respective technical and economic processes and market structure (Werthner \& Klein, 1999). It comprises digitisation of all processes and value chains in the tourism, travel, hospitality, and catering industries. At the tactical level, it includes e-commerce and applies ICTs for maximising the efficiency and effectiveness of the tourism organisation. At the strategic level, e-tourism revolutionises all business processes, the entire value chain, as well as the strategic relationships of tourism organisations with all their stakeholders (Buhalis, 2003). E-tourism affects costs, demand, and competitiveness of tourism businesses (Zelenka, 2012). Therefore, it can be stated that while e-tourism is more about the digital connections, business processes and connecting stakeholders through the Internet, smart tourism is more about connecting physical objects with digital infrastructure (Table 1). 
Table 1 The shift from e-tourism to smart tourism

\begin{tabular}{|l|l|l|}
\hline & \multicolumn{1}{|c|}{ e-Tourism } & \multicolumn{1}{c|}{ Smart Tourism } \\
\hline Sphere & digital & digital and physical \\
\hline $\begin{array}{l}\text { Core } \\
\text { technology }\end{array}$ & $\begin{array}{l}\text { Internet and web-based technology } \\
\text { (websites, social media, OTAs, GDS, } \\
\text { CRS, PMS) }\end{array}$ & $\begin{array}{l}\text { sensors, mobiles, loT, cloud } \\
\text { computing }\end{array}$ \\
\hline Travel phase & $\begin{array}{l}\text { dreaming, searching, post-trip } \\
\text { experiences }\end{array}$ & $\begin{array}{l}\text { all phases (focused mainly on during } \\
\text { the trip phase) }\end{array}$ \\
\hline Lifeblood & information & big data \\
\hline Core activities & searching, booking & $\begin{array}{l}\text { co-creation, co-decision, product } \\
\text { personalization }\end{array}$ \\
\hline
\end{tabular}

Source: own processing based on Gretzel, Sigala, Xiang, \& Koo (2015)

The shift from e-tourism to smart tourism has gained an increase attention in the scientific literature. Moreover, several destinations in the world (e.g., Amsterdam, Barcelona and Seoul), as well as the whole national policies (e.g., in Spain) has embraced smart tourism as a strategic priority for tourism development. However, as Gretzel, Reino, Kopera, \& Koo (2015) point out, as everything has become smart, definitional questions and the need for conceptualization on this phenomenon rise. Moreover, smart tourism has been mainly analysed based on the best practices in Western Europe and Asia, not dealing much with the situation in other parts of the world. Therefore, the aim of the paper is to review the conceptual foundations of smart tourism and to analyse the development of smart tourism initiative in Central Europe, specifically in Slovakia.

\section{Smart tourism ecosystem}

A smart tourism ecosystem is the most comprehensive way how to describe the conceptual foundations of smart tourism. It is based on the idea that nothing works individually, but it interacts within the ecosystem to evolve. The ecosystem is composed by different type of species (customers, market players, government) that develop strong relationships in an inclusive environment based on specific activities and business networks (Moore, 1993).

The first attempt to apply the ecosystem concept to smart tourism was proposed by Zhang, Li, \& Liu (2012), who proposed the basic concept of smart tourism based on the retrospect of the origin and development conditions of smart tourism and the comment of available concept. Later, Zhu, Zhang, \& Li (2014) expanded this concept proposing five elements of smart tourism system: tourists, government, scenic zones, businesses, and information exchange centre. Gretzel, Werthner, Koo, \& Lamsfus (2015) developed a new model consisting of touristic consumers (tourists), residential consumers (residents), tourism suppliers (tourism businesses), suppliers from other industries, 
government, media, destination management organizations, digital technologies, all embedded in a space (tourism destination). The most recent attempt was proposed by Perfetto \& Vargas-Sánchez (2018) leading to a three-level smart industrial heritage tourism business ecosystem. To summarize these concepts, smart tourism is mainly based on four elements: (1) digital technologies used by (2) consumers (tourists, residents), (3) businesses (tourism businesses, businesses from other industries), and (4) tourism destination (space governed by DMO, government).

Smart tourism is a phenomenon firmly grounded in technology (Gretzel, Reino, et al., 2015). Recent advancements such as cloud computing, sensors, and GPS widespread use, virtual and augmented reality, and the full adoption of social media and mobile technologies have pushed the emergence of smartness in tourism (Xiang \& Fesenmaier, 2017). 'Smart technologies' are specific products and services which add value to tourist experiences in a concrete manner by fostering higher interaction, cocreation, and personalisation levels (Neuhofer, Buhalis, \& Ladkin, 2012). Smart tourism takes advantage of three technological components: cloud computing, Internet of Things, and end-user internet service systems (Zhang et al., 2012). Cloud computing allows the data to be accessible and ready to use anytime and anywhere with the use of the Internet. The Internet of Things allows the connection of everyday objects, and to collect, process, and share data with a minimum human intervention. The end-user internet service systems comprise all the application and hardware that enable to use these other two technological components. They can include destination apps, augmented and virtual reality, sensors, NFC, QR codes, iBeacons, ubiquitous connectivity through Wi-Fi, latest generation websites and social networks, or chatbots (Huang, Goo, Nam, \& Yoo, 2017).

The consumer level is focused on providing intelligent support based on real-time and comprehensive understanding of tourist experience (Xiang \& Fesenmaier, 2017) and by better life quality of residents. From the tourist point of view, information technologies should enhance experience by giving all the related real-time information about the destination and its services in the planning phase, enhance access to real-time information to assist tourists in exploring the destinations during the trip, and prolong the engagement to relive the experience by providing the descent feedback after the trip (Buhalis \& Amaranggana, 2015). Smart tourism concept anticipate that tourists are smart in the sense that they want to have a supper-connected experience (Femenia-Serra, PerlesRibes, \& Ivars-Baidal, 2018). 'Smart tourist' can be therefore described as an exigent and well informed tourist, who is interested in the sustainability and responsibility of the destination $\mathrm{s} /$ he visits, wants to interact with the destination and due to his/her engagement, s/he himself becomes a co-creator and co-promoter of the destination (Gahr, Rodríguez, \& Hernández-Martín, 2014). It is the tourist who is open to sharing the data and innovations, uses smart technologies, interacts dynamically with other stakeholders, and thus co-creates his/her experience (Femenia-Serra, Neuhofer, \& Ivars-Baidal, 2018). From the residents point of view, information technologies should provide better services leading to an enhanced social and economic impact on the society (Abella, Ortiz-de-Urbina-Criado, \& De-Pablos-Heredero, 2017). 'Smart residents' are constantly 
connected, sufficiently creative and empowered, technology savvy, and actively involved in the city (Hedlund, 2012).

The business level is built on the access to shared data fostering cooperation and resource sharing among businesses (Xiang \& Fesenmaier, 2017). It incorporates the use of internal data and state-of-the-art technologies within the businesses to support marketing, profitability, and competitiveness, as well as the data from external environment supported by data sharing. 'Smart business' is able to fully integrate internal and external applications and data exchange from the cloud, obtain real time and historical data from big data and apply interconnected and interoperable systems. This will support the interlink of value systems, improve the collective efficiency and profitability of the business ecosystem, and strengthen the business competitiveness (Buhalis \& Leung, 2018). Tourism businesses operate numerous application systems such as property management systems (PMS), point of sale systems (POS), sales and marketing systems (S\&M), or customer relationship management systems (eCRM). The transactional data from these systems should be used together with real time big data from internal sensors (e.g., hotel rooms, restaurant, and lobby) and external sensors (temperature and light sensor, traffic sensor, of content sensor in social media) in order to provide valuable insights.

The destination level accompanies these previous two levels by increasing the competitiveness and enhancing quality of life of all stakeholders, including residents and tourists (Boes, Buhalis, \& Inversini, 2016). Based on the available data, the smart tourism initiative helps DMOs, local government, and tourism businesses to make real time decisions and adapt very fast to changing environment. The data sharing in a tourism destination requires intelligent information system that interconnects all the stakeholders in a destination, integrate data from different sources, and allows dynamic sharing and real-time decision making (Buhalis \& Amaranggana, 2015; Gajdošík, 2019). The idea of smart tourism destination is derived from the concept of smart city, where smartness is incorporated in mobility, living, people, governance, economy, and environment (Giffinger et al., 2007). A smart city can be defined as a city that is supported by a pervasive presence and massive use of advanced information technologies, which, in connection with various urban systems and domains, enables the city to control available resources safely, sustainably, and efficiently in order to improve economic and societal outcomes (Bibri \& Krogstie, 2017). Smart cities are knowledge centres that manage information, technology, and innovation, trying to reach efficient management, sustainable development, and a better quality of life for residents (Caragliu, Del Bo, \& Nijkamp, 2011). Since the inception in the urban environment, the smart approach has been applied also to tourism destinations (Ivars-Baidal, Celdrán-Bernabeu, Mazón, \& Perles-Ivars, 2017). Implementing the smart concept in a tourism destination has been crucial since the connected, better informed, and engaged tourist is dynamically interacting with the destination leading to the need of co-creating tourism product and adding value for all tourism stakeholders (Neuhofer et al., 2012). 'Smart tourism destination' can be defined as an innovative tourism destination built on an infrastructure of the state-of-the-art technology, which guarantees the sustainable development of tourist areas, facilitates the visitor's interaction with and integration into his or her surroundings, increases the quality of the experience 
at the destination, and improves residents' quality of life (Avila, 2015). In a smart destination, DMO should function as smart hubs that coordinates all relevant information and makes it easily accessible for users to access them in real-time. By digitalisation of core business processes, precise market targeting, service provision, and proactiveness, it cocreates a tourism experience (Hedlund, 2012). It should be the centre of excellence, as well as innovation leader in tourism. The role of local government is to support open data, regulate data privacy and support public private partnership (Buhalis \& Amaranggana, 2015; Hedlund, 2012). For the analysis of smart tourism destinations, the (SA) ${ }^{6}$ framework is worth using. This framework is based on Buhalis' (2000) 6A framework for the analysis of tourism destinations, later adapted by Tran, Huertas, \& Moreno (2017) to the smart destination concept. It consists of smart attractions, smart accessibility, smart amenities, smart ancillary, smart activities, and smart available packages.

Based on the above mentioned literature, the smart torurism ecosystem is designed (Figure 1). It expresses the elements and their relationships based on the smart tourism concept.

Figure 1 The smart tourism ecosystem

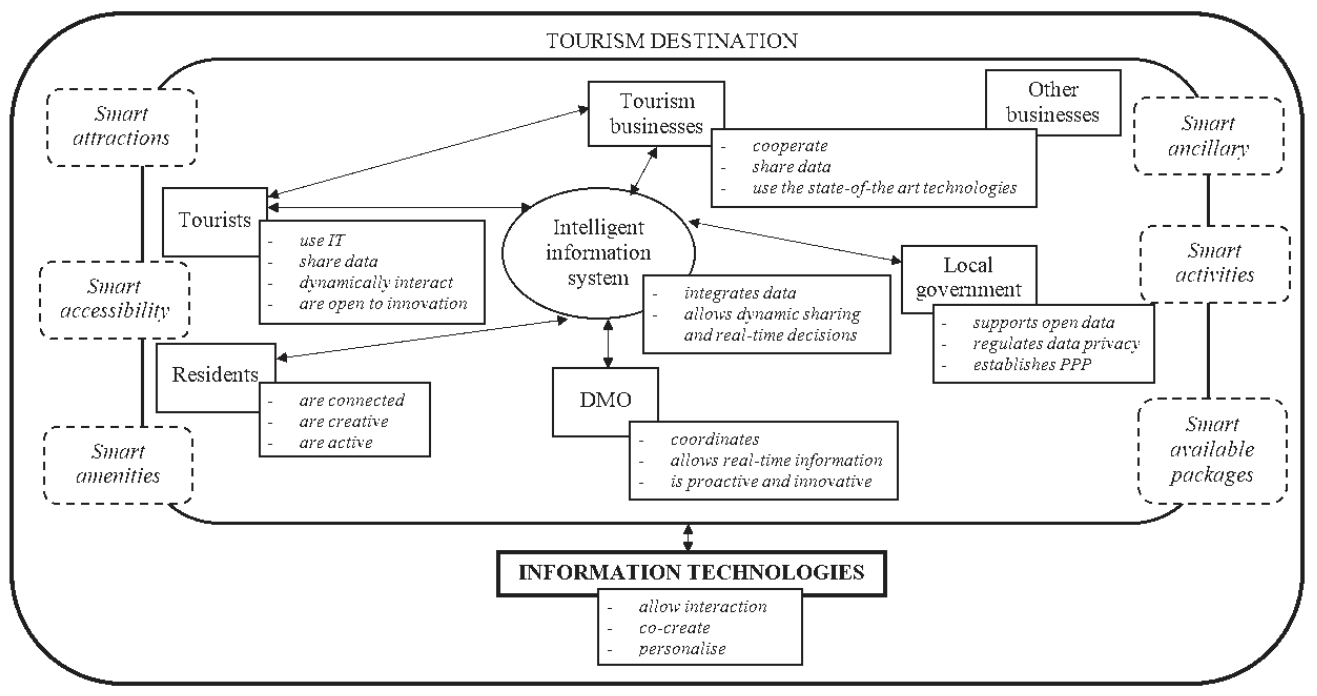

Source: own processing

Despite the fact that smartness is viewed mainly as focusing on new information technologies, it can be affirmed that technology is a necessary condition, but not sufficient to create smart tourism. It is also important to stress the ability to share knowledge and innovation within destination stakeholders. Boes et al. (2016) claim that the use of information technologies is defined as 'hard smartness', while the soft aspect of smartness is also needed. Therefore, the right decisions can be made based on the data gained. This 'soft smartness' is fostered by open innovation, supported by investments in human and 
social capital, and sustained by participatory governance in order to develop the collective competitiveness to enhance social, economic, and environmental prosperity for all stakeholders leading to sustainable competitive advantages.

\section{Methodology}

The aim of this paper is to review the conceptual foundations of smart tourism and to analyse the development of smart tourism initiative in Central Europe, specifically in Slovakia. Slovakia was chosen as a reference country, where the use of the Internet services and integration of digital technology is at the average level of the European Union countries (European Commission, 2018). Therefore, this article presents an undistorted view on smart tourism and deals with the problems of its development.

The paper adopts an exploratory multiple case study methodology. This kind of methodology uses case studies to monitor contemporary events and behaviour (Vecchio, Mele, Ndou, \& Secundo, 2017). The multiple case design is a research methodology in which several instrumental, bounded cases are examined using multiple data collection methods. This research methodology is more powerful than single-case designs as it provides more extensive descriptions and explanations of the phenomenon or issue (Mills, Durepos, \& Wiebe, 2010). The case studies are structured as follows: firstly, the role of information technologies during the tourist journey is examined to find out if tourists from Central Europe are 'smart'. Then the tourism businesses are examined in terms of data sharing and the use of the state-of-the-art technologies in Slovak hotels is analysed. In the selected smart cities, the smart tourism concept was studied and the national level is incorporated in the National Tourist System of Slovakia.

The paper used primary and secondary data. The source of primary data was a structured questionnaire aimed at the identification of buying behaviour of tourists from Central Europe. The frequency of use of information technologies was measured on the Likert scale (0 - never, 1 - seldom, 2 - sometimes, 3 - often, 4 - regularly). The questionnaire was distributed using CAPI and CAWI methods. The research sample consisted of 5,975 respondents from Slovakia. The research sample was representative, taking into account the age of the respondents. The frequencies of respondents' age, education and salary are presented in Table 2.

In order to find out attitudes of destination stakeholders towards the data sharing, a survey among 111 tourism businesses in Slovakia was performed. Moreover, 75 hotels were questioned to discover the use of modern information technologies. The secondary data was used to examine smart destination initiatives in three selected Slovak destinations - Nitra, Banská Bystrica, and Košice. The smart initiative at the national level was examined based on the secondary data of the National Tourist Information System of Slovakia. 
Table 2 Frequencies of respondents' age, education, and salary

\begin{tabular}{|c|c|c|c|c|c|c|c|c|}
\hline \multicolumn{3}{|c|}{ Age } & \multicolumn{3}{|c|}{ Education } & \multicolumn{3}{|c|}{ Salary } \\
\hline $\begin{array}{l}\stackrel{0}{\mathscr{D}} \\
\stackrel{\mathbb{0}}{\widetilde{0}} \\
\simeq\end{array}$ & 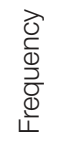 & 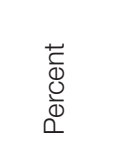 & 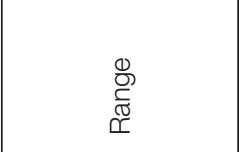 & 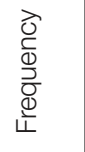 & $\begin{array}{l}\overrightarrow{\widetilde{J}} \\
\overline{0} \\
\frac{0}{0} \\
0\end{array}$ & 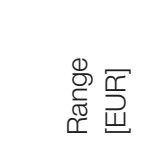 & 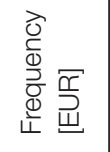 & $\begin{array}{l}\text { त्र } \\
\overline{0} \\
\frac{0}{0} \\
0\end{array}$ \\
\hline $0-24$ & 631 & $10.56 \%$ & primary & 70 & $1.17 \%$ & $0-599$ & 1015 & $16.99 \%$ \\
\hline $25-34$ & 1308 & $21.89 \%$ & secondary & 2879 & $48.18 \%$ & $600-1200$ & 2985 & $49.96 \%$ \\
\hline $35-44$ & 1582 & $26.48 \%$ & tertiary - Bachelor & 643 & $10.76 \%$ & 1300-1999 & 1439 & $24.08 \%$ \\
\hline $45-54$ & 1171 & $19.60 \%$ & tertiary - Master & 2330 & $39.00 \%$ & \multirow[t]{3}{*}{$2000+$} & \multirow[t]{3}{*}{536} & \multirow[t]{3}{*}{$8.97 \%$} \\
\hline $55-64$ & 834 & $13.96 \%$ & tertiary - PhD. & 45 & $0.75 \%$ & & & \\
\hline $65+$ & 449 & $7.51 \%$ & other & 8 & $0.13 \%$ & & & \\
\hline$\Sigma$ & 5975 & $100.00 \%$ & $\Sigma$ & 5975 & $100.00 \%$ & $\Sigma$ & 5975 & $100.00 \%$ \\
\hline
\end{tabular}

Source: own processing

\section{Results}

The emergence of new information technologies, as well as the change in the buying behaviour of tourists' force tourism managers to adopt new processes, leading to better fulfilment of all stakeholders' needs. The challenge is to provide real-time personal services to visitors and interconnect all stakeholders in order to share information and knowledge and to make tourism destinations smarter.

\section{Smart tourists}

Information technologies have been integrated to everyday life. Therefore, they also influence the buying behaviour of tourists. This behaviour is known as a tourist journey and has several stages (e.g., dreaming, planning, booking, visiting, post visit recollection, recommendation). In terms of information technologies, three main stages are important - searching, booking, and activities during the stay in the destination. In order to find the significance of using the different forms of media used by tourists during their journey, a survey was conducted among the Central European tourists (Figure 2).

During the searching and booking phase, the most significant are search engines (e.g., Google), word-of-mouth marketing, hotel website, internet distribution systems (IDS, e.g., booking.com), and online travel agencies (OTA, e.g., Expedia). Moreover, tourists are also searching for information on social networks (e.g., Facebook), in travel agencies, on destinations' web, and review sites (e.g., TripAdvisor). In the last years, the significance of sharing economy platforms (e.g., AirBnB) and meta search engines (e.g., Trivago) has been rising steadily in Central Europe. 
Figure 2 Significance of different types of media during the tourist journey

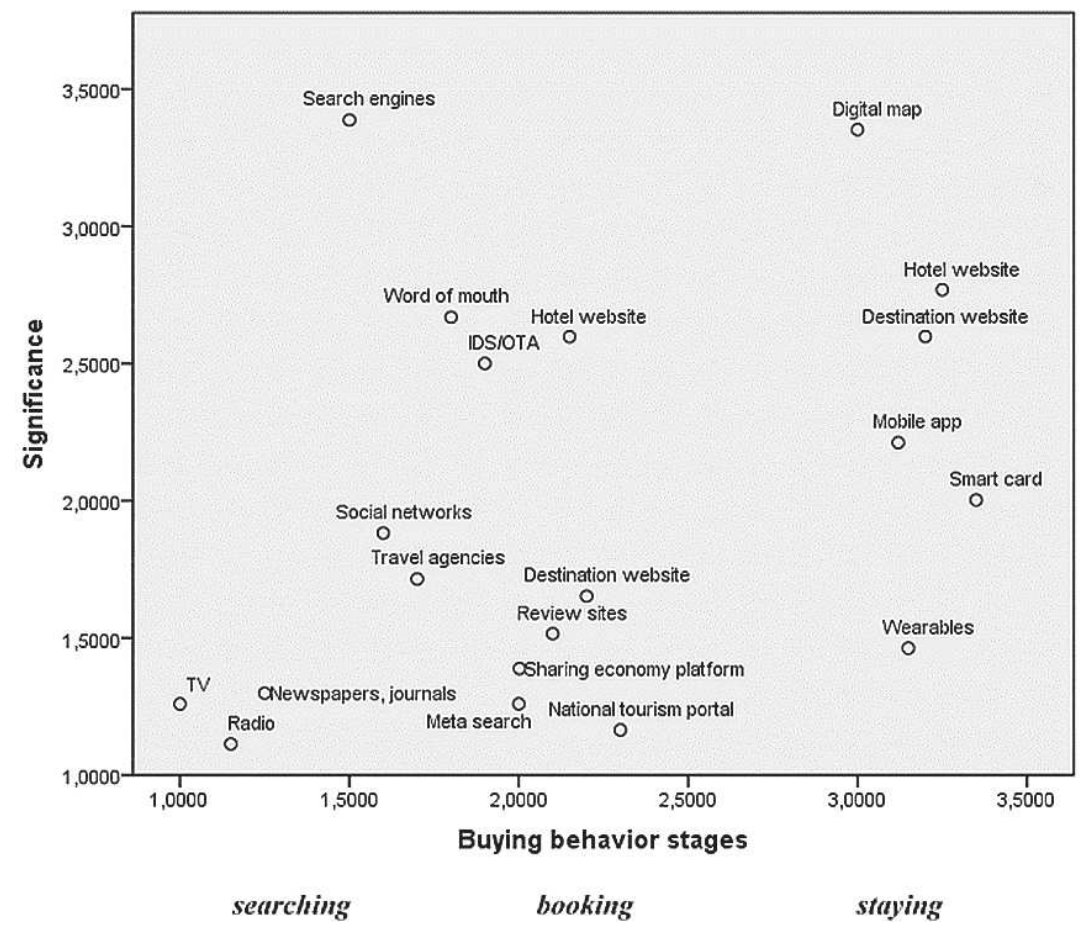

Source: own processing

During the stay in the destination, tourists use digital maps to find directions within the destination. Hotels' and destinations' websites provide important information on services, while the mobile apps integrate all the above mentioned services. Tourists also use smart destination cards, which integrate free services (e.g., transport) or provide discount for services in a destination. As a result of technology shrinking, wearables (e.g., smart watches or glasses) started to be used by technology-aware tourists.

It was proved that the willingness to use information technologies during the journey was high among the Central European tourists. Therefore, this fact indicates the opportunity to focus on the smart tourism initiative in this geographical area.

\section{Smart tourism businesses}

From the business perspective, it is important to make knowledge and information accessible to all stakeholders in an efficient way and thus to enable them to participate as much as possible in the innovation process. Tourism business should be dynamically linked with information technologies, which enable them to create, collect, and exchange 
real time information. Therefore, the most important thing is to make businesses collaborate and share their data.

In order to find out the willingness of data sharing, a survey was performed among 111 tourism stakeholders. These stakeholders include accommodation and hospitality facilities, tour operators, organizers of events, and spa facilities. These stakeholders were asked to express their opinions on positive and negative aspects of sharing data.

From the positive point of view (Figure 3), more than $60 \%$ of businesses see in the sharing of data the opportunity for a better exchange of information. They also see the opportunity for knowledge sharing as the shared data includes valuable information for their strategic decisions. $27 \%$ of businesses are aware that the sharing of data will lead to the reduction of communication costs and $13 \%$ see the opportunity for the inclusion of a destination into the booking system.

Figure 3 The positive aspects of sharing data among tourism businesses

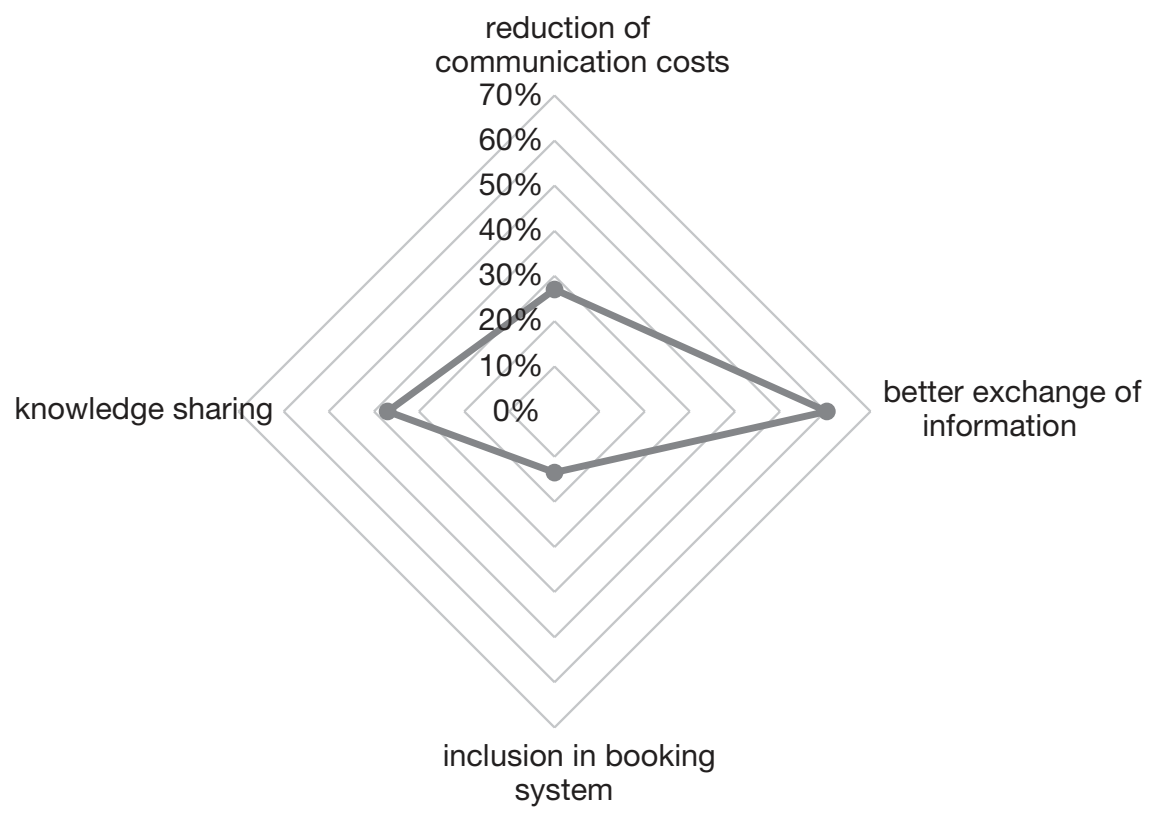

Source: own processing

The negative answers (Figure 4) indicate that almost $50 \%$ of stakeholders have the fear of misusing the data for someone's own purposes. $40 \%$ of respondents have the lack of confidence in the sharing of data and almost $23 \%$ have the fear of leakages and do not want to take risk of financial loses. 
Figure 4 The negative aspects of sharing data among tourism businesses

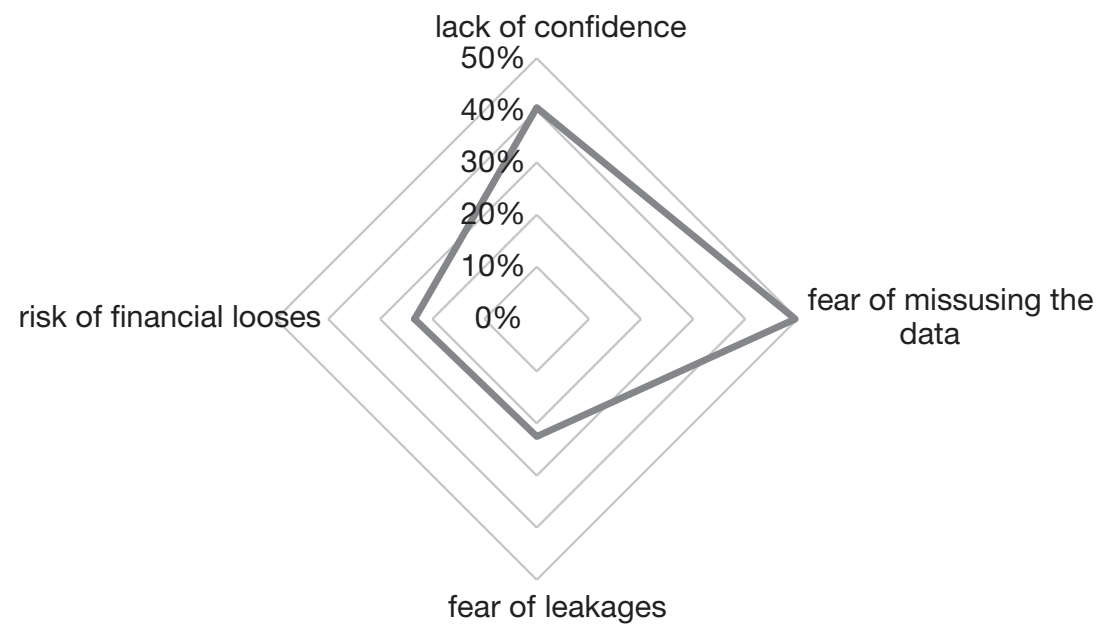

Source: own processing

Figure 5 The use of the state-of-the-art technologies in Slovak hotels

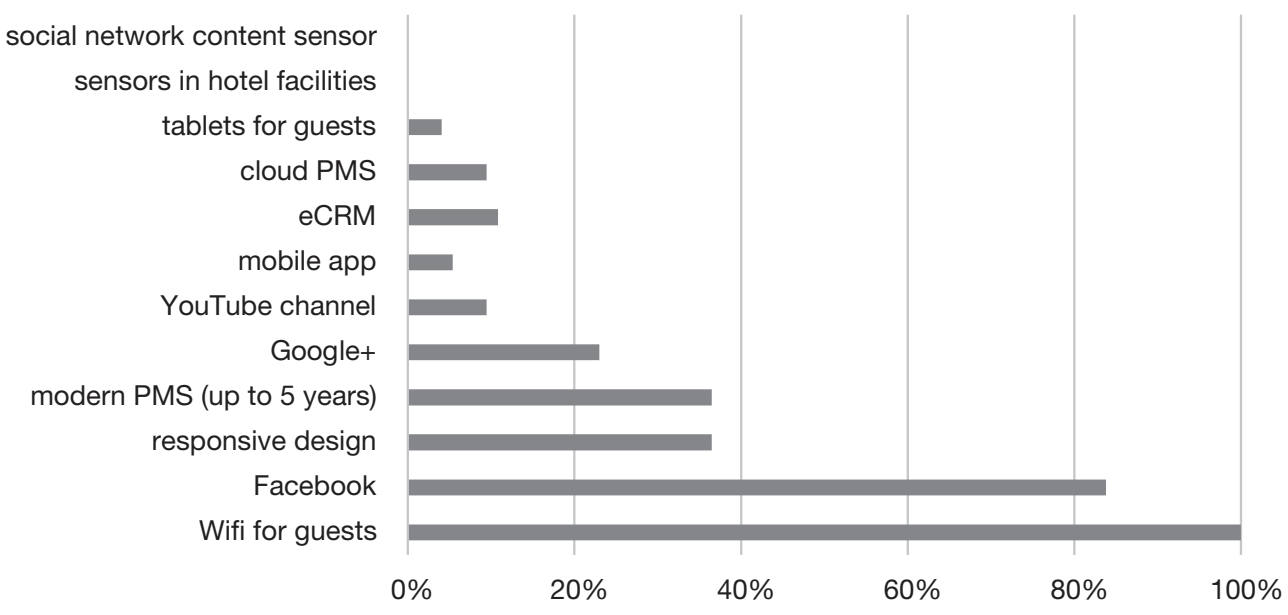

Source: own processing

The negative aspects of sharing data are connected with the low understating of coopetition in tourism destinations. Many tourism businesses in Slovakia do not understand that in order to attract more tourists and provide them with a better experience and services, it is important to cooperate, rather than compete. 
From the business perspective, it is also important to analyse the use of information technologies within the business operation. In terms of the use of the state-of-the-art technologies, a survey among 75 hotels was conducted (Figure 5). All of the questioned hotels offer free Wi-Fi for their guests and more than $85 \%$ of them use Facebook as a social medium. $36 \%$ of the hotels have modern PMS, not older than 5 years. However, only a small share of the hotels uses eCRM, cloud computing, and none of the questioned hotels uses sensors in their own facilities or social network content sensors for real-time monitoring of social networks.

The analysis of smart tourism businesses reveals that the tourism businesses in Slovakia are very slowly adopting the smart conception. The cooperation is very low, resulting in unwillingness of sharing data. Moreover, the use of the state-of-the-art technologies is limited to Wi-Fi and social media, not integrating the sensor technologies as a baseline for the smart conception.

\section{Smart tourism destinations}

The application of the smart tourism concept in a destianation can strenghten its competitive position and lead to better satisfation of tourist's needs. The selected three tourism destinations (Nitra, Banská Bystrica, and Košice) were chosen as a research sample because several smart tourism initiatives are being implemeted nowadays in these cities. However, based on the benchmarking with other European medium-sized cities, it can be stated that the selected destinations are below the average of all European cities (Figure 6). The shorcomings can be seen mainly in 'smart economy' and 'smart people'.

Figure 6 The smart city index of the examined destinations

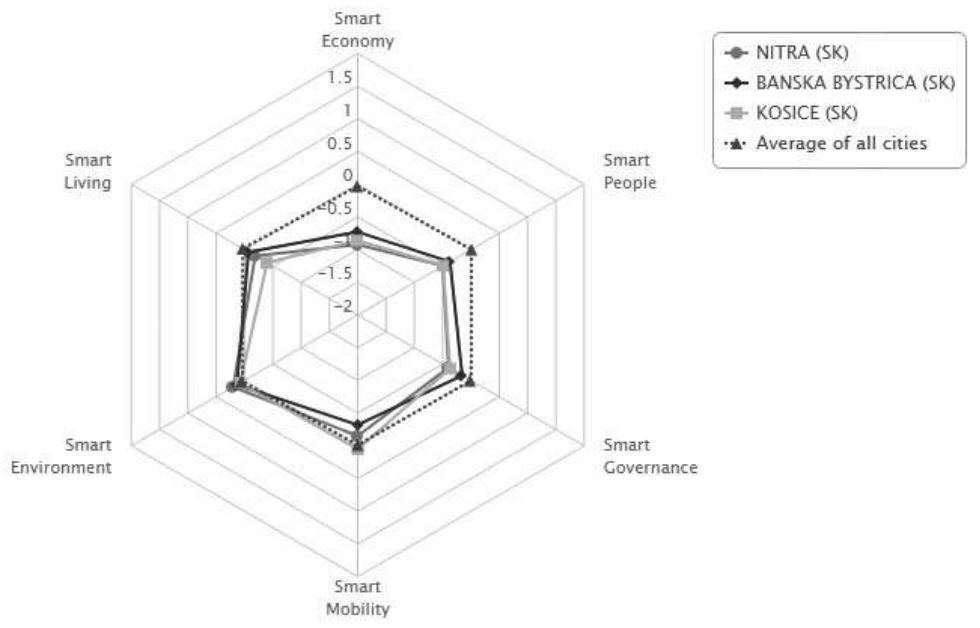

Source: www.smart-cities.eu 
However, it should be noted that the smart city initiative is being supported by the European Commision as the cities should become the development poles. Therefore some improvements will take place soon in these cities.

From the tourism point of view, the smart conception is examined based on the framework of (SA) ${ }^{6}$ (Table 3), consisting of smart attractions, smart accessibility, smart amenities, smart ancillary, smart activities, and smart available packages (Tran et al., 2017).

Table 3 Smart initiatives in the examined tourism destinations, based on the $(\mathrm{SA})^{6}$ framework

\begin{tabular}{|c|c|c|c|}
\hline & Nitra & Banská Bystica & Košice \\
\hline $\begin{array}{l}\text { Smart } \\
\text { attractions }\end{array}$ & $\begin{array}{l}\text { info kiosk } \\
\text { audio guide (synagogue) }\end{array}$ & $\begin{array}{l}\text { info kiosk } \\
\text { sensors for crowd } \\
\text { monitoring } \\
\text { iBeacons }\end{array}$ & $\begin{array}{l}\text { info kiosk } \\
\text { botanic garden app }\end{array}$ \\
\hline $\begin{array}{l}\text { Smart } \\
\text { accessibility }\end{array}$ & $\begin{array}{l}\text { free Wi-Fi in the city } \\
\text { centre } \\
\text { real time monitoring } \\
\text { of transport situation } \\
\text { bike sharing }\end{array}$ & $\begin{array}{l}4 G \text { internet connection in } \\
\text { the city centre } \\
\text { free Wi-Fi in the public } \\
\text { areas } \\
2 \text { digital bus stops }\end{array}$ & $\begin{array}{l}\text { free Wi-Fi in the public } \\
\text { areas and bus stops } \\
\text { real time monitoring of } \\
\text { public transport } \\
\text { parking system Park and } \\
\text { Display }\end{array}$ \\
\hline $\begin{array}{l}\text { Smart } \\
\text { amenities }\end{array}$ & $\begin{array}{l}\text { Nitra Tourist Board } \\
\text { energy management } \\
\text { system }\end{array}$ & $\begin{array}{l}\text { Central Slovakia Tourist } \\
\text { Board } \\
\text { CRS-destination booking } \\
\text { engine }\end{array}$ & Košice Tourist Board \\
\hline $\begin{array}{l}\text { Smart } \\
\text { ancillary }\end{array}$ & smart city initiative & $\begin{array}{l}\text { smart city initiative } \\
\text { smart communities } \\
\text { (Garden - centre of } \\
\text { independent culture) }\end{array}$ & $\begin{array}{l}\text { smart city initiative } \\
\text { smart communities } \\
\text { focused on history and } \\
\text { culture }\end{array}$ \\
\hline $\begin{array}{l}\text { Smart } \\
\text { activities }\end{array}$ & $\begin{array}{l}\text { management of activities } \\
\text { in a participatory and } \\
\text { collaborative way }\end{array}$ & $\begin{array}{l}\text { quick access to third party } \\
\text { leisure source } \\
\text { use of DMS } \\
\text { management of activities } \\
\text { in a participatory and } \\
\text { collaborative way }\end{array}$ & $\begin{array}{l}\text { quick access to third party } \\
\text { leisure source } \\
\text { management of activities } \\
\text { in a participatory and } \\
\text { collaborative way }\end{array}$ \\
\hline $\begin{array}{l}\text { Smart } \\
\text { available } \\
\text { packages }\end{array}$ & $\begin{array}{l}\text { smart tourist card } \\
\text { tourist mobile app }\end{array}$ & tourist mobile app & $\begin{array}{l}\text { tourist mobile app } \\
\text { initiative Invisible hotel }\end{array}$ \\
\hline
\end{tabular}

Source: own processing

All the examined destinations have done some steps in all of the 6 areas of the framework. These destinations have info kiosk to inform tourists about their attractions. Moreover, they provide free Internet access in most of the public spaces. Following the Tourism support act (2010), all the examined destinations have established a destination management organization as a public-private partnership initiative. Destinations 
Figure 7 Dashboards from the National Tourist Information System on Slovakia

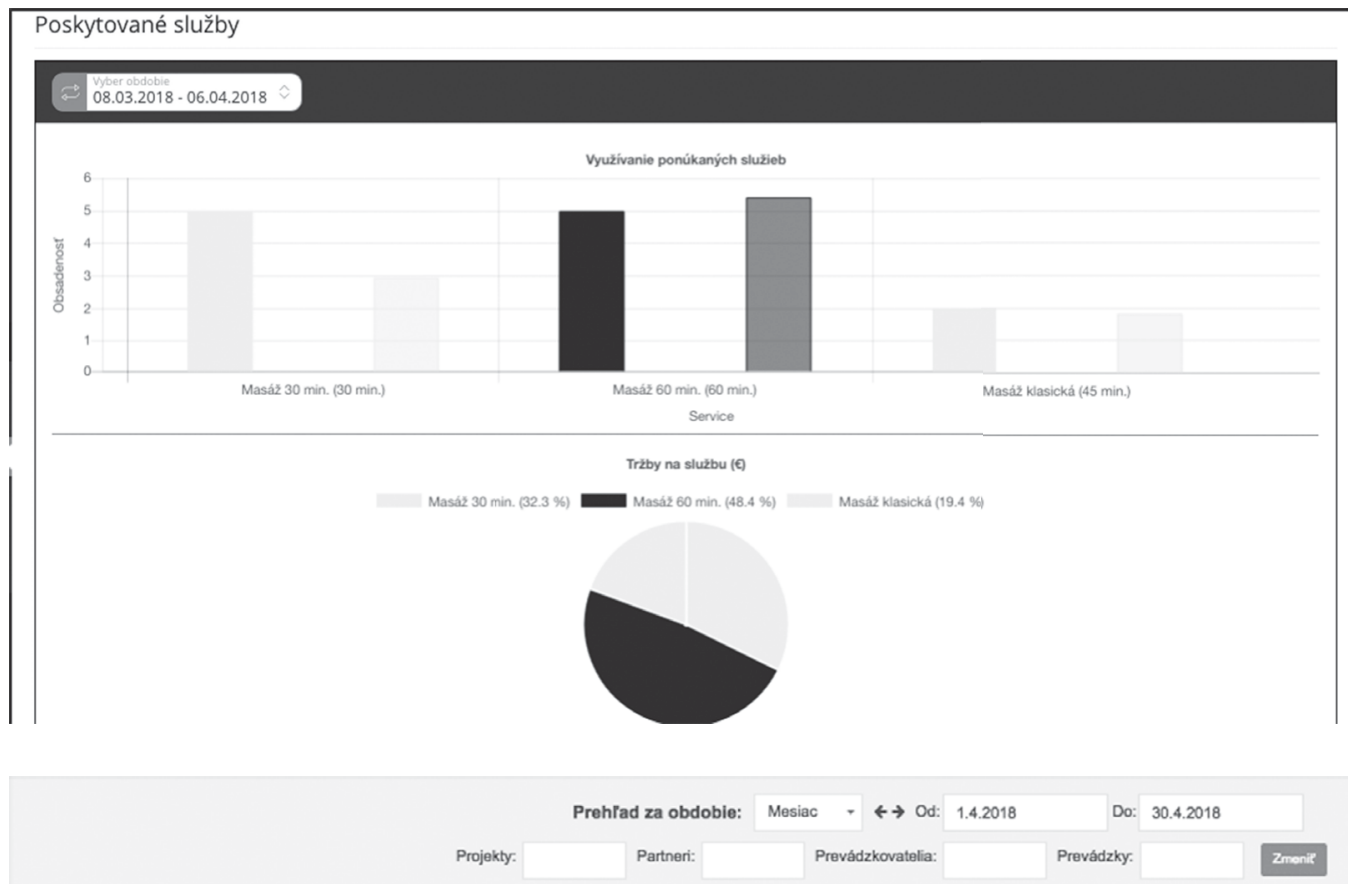

Počet identifikácii

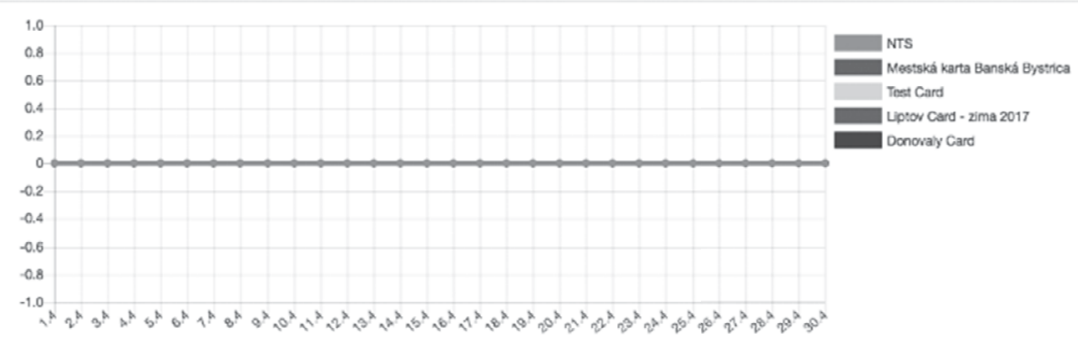

Pocet bodov

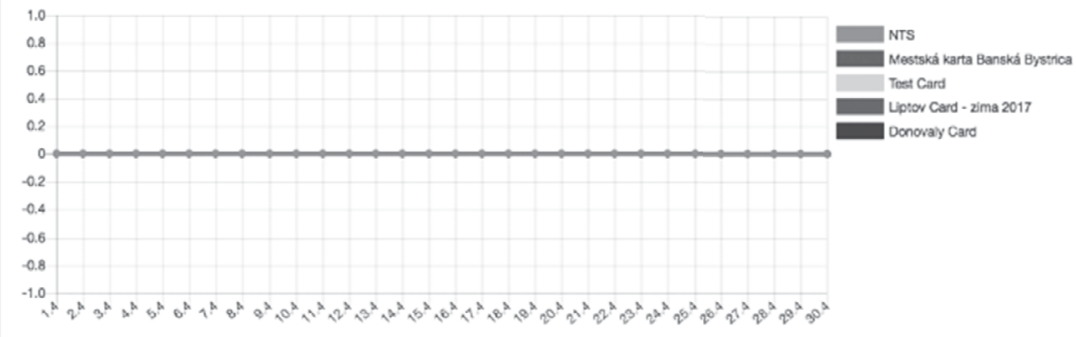



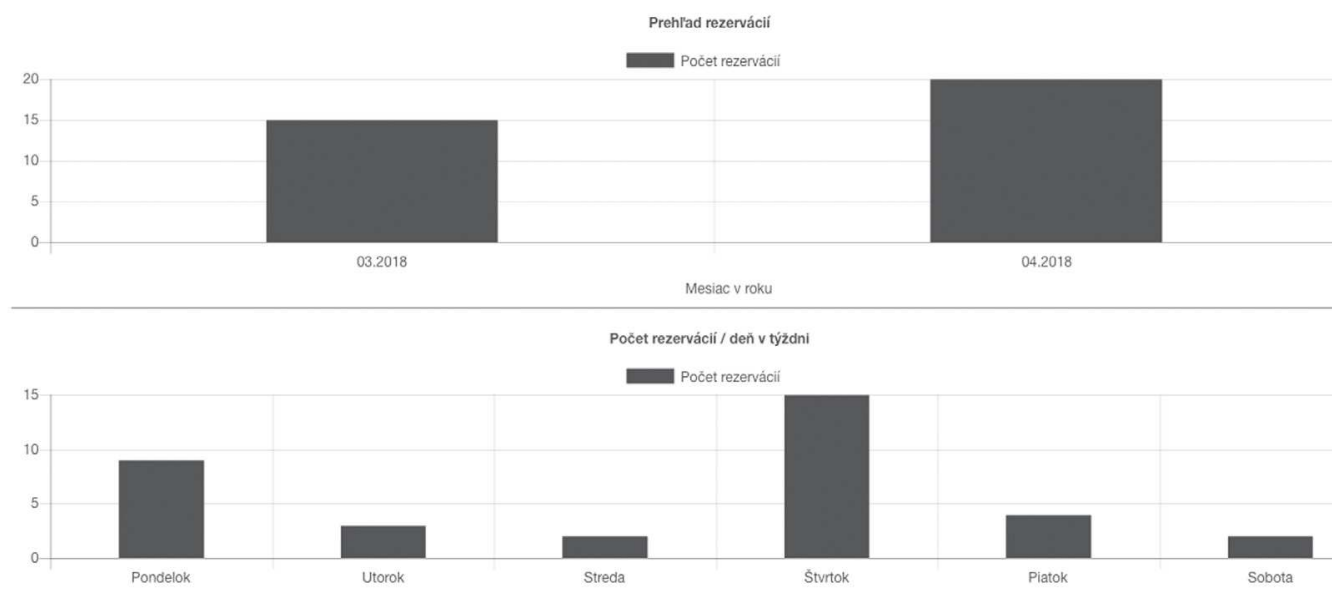

Source: Interal material of MVI, Inc. (2018)

also provide mobile apps for their tourists. Banská Bystrica and Košice try to support local communities and have a quick access to the third party leisure source through the official tourist web sites. Nevertheless, it can be stated that the application of the smart conception in tourism destinations in Slovakia is still very limited comparing to other European city destinations (e.g., Amsterdam, Barcelona). However, the major initiative is done on a national scale.

The smart tourism destination initiative in Slovakia is more supported at the national level. The National Tourist System has been developed as a complex set of tools for tourists and is being introduced now. It consists of a tourist web-based portal (www.slovakia. travel), mobile app, and tourist card. Therefore, the tourist has everything $\mathrm{s} / \mathrm{he}$ needs for a full trip.

The web-based portal has been augmented by trip planner with the possibility of booking services (accommodation, tickets), which together with searching functions provide valuable big data on tourist behaviour. The national tourist card should be implemented into the bank cards by cooperation with MasterCard. The card will be used for payments, collection of loyalty points, and providing other benefits. Thanks to the Token technology, the cards will be used whenever and wherever the contactless technology is available (e.g., transport, accommodation, events, skipasses). The mobile app extends the functionality of the web portal and provide navigation to points of interests. It can be also used as a virtual guide and hotel assistant with the ability to provide feedback to purchased services.

The system has a comprehensive administration system and interfaces with other systems (such as booking.com). The content management system can be accessed by several users, who are responsible for their own part. The system gathers big data and provide comprehensive dashboards (Figure 7) for smart decisions. 


\section{Discussion}

The conceptualization of smart tourism by smart tourism ecosystem led to the differentiation of four main elements (smart technologies, smart consumers, smart businesses, and smart destinations). Smart technologies create value for tourists, enable tourism businesses and DMOs to share knowledge, better understand tourists' needs, create personalized products, and thus to be more efficient and competitive. Thanks to the use of technologies, big data is created. Big data requires new techniques and algorithms to be used. These techniques may include data mining focusing on discovering new knowledge and patterns in big data. A useful method is also machine learning, where supervised learning uses training data to develop an algorithm for classifying new examples, or unsupervised learning using unlabelled input data to explore and discover hidden patterns. The use of text mining and sentiment analysis is also welcomed. Nowadays, the artificial intelligence is started to be used in the tourism industry for vacation planning (e.g., IMB Watson Advertising) or for concierge services (e.g., IMB Ivy). There is also a need for a conceptualisation of a technological platform on which information relating to tourism activities could be exchanged instantly and which will dynamically interconnect destination stakeholders (Buhalis \& Amaranggana, 2015). The added value of such an intelligent information system for the smart tourism destinations is in the provision of useful information on behaviour, movement, timetable, and visitation of tourist attractions, real-time processing of all collected data and offering a platform for open data exchange and decision making (Gajdošík, 2019).

Moreover, as Femenia-Serra et al. (2018) emphasise, technology has not been enough examined from the tourists' perception of the specific uses, which may be given in the smart context. Smart tourism has uncritically assumed that tourists want to use information technologies for multiple purposes, in every context and all the time, and that they want to interact with stakeholders in a dynamic and open way. As our research revealed, tourists used information technologies during their journey to a large extent. However, based on the research of Femenia-Serra, Perles-Ribes, et al. (2018), the interaction is still very limited. The problem can be partially solved by using volunteered geographical information (VGI), which is a reliable source of Big data (Baggio \& Scaglione, 2018). There is also the problem of privacy and security while sharing data. Nevertheless, for many tourists the vacation is a time to 'unplug' and they use tourism for digital detox. It is related with the Benckendorff, Moscardo, \& Murphy (2005) research on high-tech and high-touch travellers distinguishing tourists based on the use of information technologies during travel and everyday life. Therefore, more research should be done on the acceptance of information technologies during the travel journey.

Although businesses also want to become smart to be more effective and support their competitiveness, due to the fragmented nature of tourism industry and small size of tourism business, tourism stakeholders lag behind other stakeholders. The sharing of data is reduced by the fear of misusing the data, lack of confidence, fear of leakages, and risk of financial loses. These arguments are supported by the innovation barriers of tourism businesses, which include fear of risk, lack of time, and money and unwillingness to 
cooperate (Gajdošíková, 2017). The case study of Slovak tourism businesses reveals the shortcomings in sharing data resulting from not understanding the coopetition in tourism destinations, as well as the insufficient use of the state-of-the-art technologies.

The smart destination concept has been transforming mainly city destinations all over the world. As claimed by Gretzel, Sigala, et al. (2015), there is an incredible institutional support and in some cases, even pressure to implement the smart concept in destinations. Especially in Asia, there have been efforts to drive the smart tourism agenda forward. Governments in China and South Korea are heavily funding initiatives, mostly focused on building technological infrastructure. In Europe, the European Commission supports the smart destinations by the European capital of smart tourism. Moreover, in Spain, the national tourism policy has adopted the smart approach and together with Segittur, the state-owned company for the management of innovation and tourism technologies, is developing the standards for smart tourism destinations. The Slovak destinations have implemented some smart initiatives focusing on tourism, however, it is not enough for them to be claimed as 'smart destinations'. To take the full advantage of the smart concept, the Slovak destination managers should focus more on the implementation of information technologies and their interconnectivity, as well as on knowledge sharing, cooperation, and leadership. On the other hand, the national initiative, based on the National Tourist Information System, is slowly pushing forward the smart concept.

\section{Conclusion}

The smart tourism concept leads to better fulfilling the expectations of visitors by providing personalized products and provides new challenges to tourism businesses and destination management organizations to collect data and to create more competitive product. All tourism stakeholders should be involved in knowledge exchange, collaboration, and value creation to form a smart tourism environment. The combination of information technologies together with informed stakeholders led by the innovation oriented DMOs can enhance the potential of tourism destination and lead to the creation of competitive advantage. As Ivars-Baidal, Celdrán-Bernabeu, Mazón, \& Perles-Ivars (2017) emphasise, although the maximum impact of emerging technologies will take place in short term (2-5 years), the true development of smart tourism will occur in this period. It is also the case of Slovakia, where tourism businesses and destinations have just started to use some smart features. On the other hand, the use of information technologies among tourists is very high, indicating the opportunity to push the development of smart tourism in Central Europe from the demand side.

The conceptualisation of smart tourism revealed that smart tourism should not be an ultimate goal, but with the help of technology, innovation, and cooperation, it should bring a better tourist experience, wellbeing of residence, enhance effectiveness and competitiveness of businesses and destinations, and lead to overall competitive sustainability (Figure 8). 
Figure 8 The goal of smart tourism

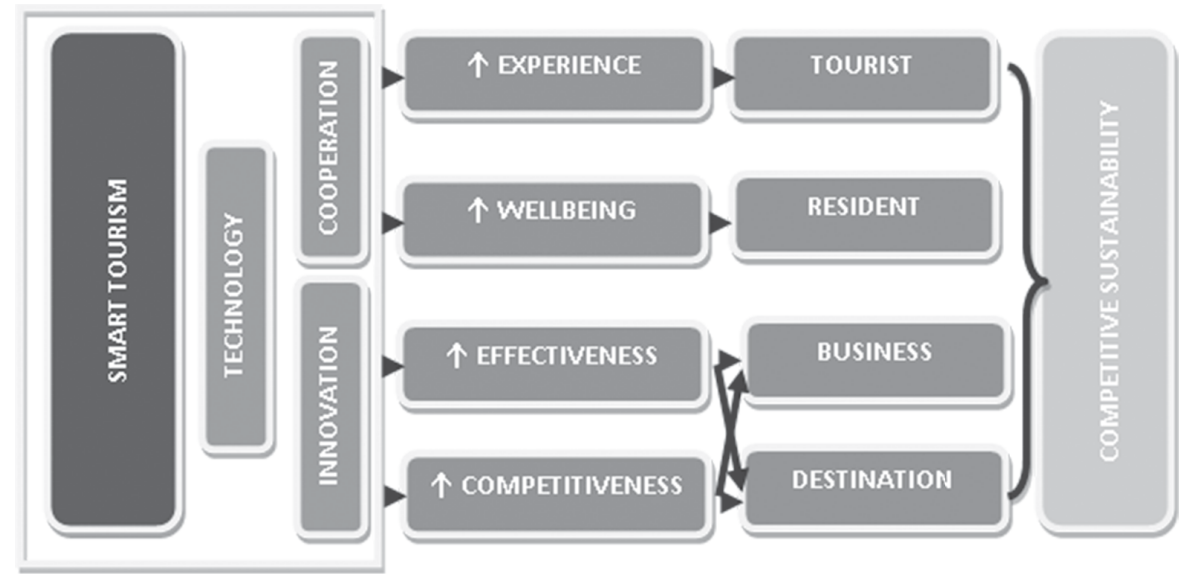

Source: own processing

The presented study offers valuable information from a country that is among the average European Union countries in the Internet services usage and integration of digital technologies. Although it does not provide the examples of best practices, it shows the real conditions and problems of the smart tourism development. The findings can be useful for countries that start introducing the smart tourism development, as well as for decision makers that are struggling with this phenomenon.

\section{References}

Abella, A., Ortiz-de-Urbina-Criado, M., \& De-Pablos-Heredero, C. (2017). A model for the analysis of data-driven innovation and value generation in smart cities' ecosystems. Cities, 64, 47-53. DOI: 10.1016/j.cities.2017.01.011.

Aina, Y. A. (2017). Achieving smart sustainable cities with GeoICT support: The Saudi evolving smart cities. Cities, 71(August 2016), 49-58. DOI: 10.1016/j.cities.2017.07.007.

Avila, L. de. (2015). Smart destinations: XXI century toruism.

Baggio, R., \& Scaglione, M. (2018). Strategic visitor flows and destination management organization. Information Technology and Tourism, 18(1-4), 29-42. DOI: 10.1007/s40558-017-0096-1.

Benckendorff, P., Moscardo, G., \& Murphy, L. (2005). High Tech versus High Touch: Visitor Responses to the Use of Technology in Tourist Attractions. Tourism Recreation Research, 30(3), 37-47. DOI: 10.1080/02508281.2005.11081485.

Benckendorff, P., Sheldon, P., \& Fesenmaier, D. (2014). Tourism information technology. Oxfordshire: CABI International.

Bibri, S. E., \& Krogstie, J. (2017). The core enabling technologies of big data analytics and contextaware computing for smart sustainable cities: a review and synthesis. Journal of Big Data, 4(1), 38. DOI: $10.1186 / \mathrm{s} 40537-017-0091-6$. 
Boes, K., Buhalis, D., \& Inversini, A. (2016). Smart tourism destinations: ecosystems for tourism destination competitiveness. International Journal of Tourism Cities, 2(2), 108-124. DOI: 10.1108/ IJTC-12-2015-0032.

Buhalis, D. (2000). Marketing the competitive destination of the future. Tourism Management, 21(1), 97-116. DOI: 10.1016/S0261-5177(99)00095-3.

Buhalis, D. (2003). eTourism. Information technology for strategic tourism management. Edinburgh: Pearson Education Limited.

Buhalis, A., \& Amaranggana, A. (2015). Smart Tourism Destinations Enhancing Tourism Experience Through Personalisation of Services. In I. Tussyadiah \& A. Inversini (Eds.), Information and Communication Technologies in Tourism 2015 (pp. 377-389). Cham: Springer International Publishing Switzerland. DOI: 10.1007/978-3-319-14343-9_28.

Buhalis, D., \& Leung, R. (2018). Smart hospitality-Interconnectivity and interoperability towards an ecosystem. International Journal of Hospitality Management, 71(April), 41-50. DOI: 10.1016/j. ijhm.2017.11.011.

Caragliu, A., Del Bo, C., \& Nijkamp, P. (2011). Smart Cities in Europe. Journal of Urban Technology, 18(2), 65-82. DOI: 10.1080/10630732.2011.601117.

European Commission. (2018). Digital economy and society index 2018. Country report Slovakia.

Femenia-Serra, F., Neuhofer, B., \& Ivars-Baidal, J. A. (2018). Towards a conceptualisation of smart tourists and their role within the smart destination scenario. The Service Industries Journal, 38(16). DOI: 10.1080/02642069.2018.1508458.

Femenia-Serra, F., Perles-Ribes, J. F., \& Ivars-Baidal, J. A. (2018). Smart destinations and tech-savvy millennial tourists : hype versus reality. Tourism Review, 2(June). DOI: 10.1108/TR-02-20180018.

Gahr, D., Rodríguez, Y., \& Hernández-Martín, R. (2014). Smart Destinations. The Optimisation of Tourism Destination Management. In Seminario de Economía Canaria. Tenerife, Islas Canarias, Spain.

Gajdošík, T. (2019). Towards a Conceptual Model of Intelligent Information System for Smart Tourism Destinations. In R. Silhavy (Ed.), Software Engineering and Algorithms in Intelligent Systems (pp. 66-74). Springer, Cham. DOI: 10.1007/978-3-319-91186-1_8. (In print).

Gajdošíková, Z. (2017). Inovácie v cestovnom ruchu. Banská Bystrica: Belianum.

Giffinger, R., Fertner, C., Kramar, H., Kalasek, R., Pichler-Milanovic, N., \& Meijers, E. (2007). Smart cities. Ranking of European medium-sized cities. Vienna.

Gretzel, U. (2011). Intelligent systems in tourism: A Social Science Perspective. Annals of Tourism Research, 38(3), 757-779. DOI: 10.1016/j.annals.2011.04.014.

Gretzel, U., Reino, S., Kopera, S., \& Koo, C. (2015). Smart Tourism Challenges. Journal of Tourism, 16(1), 41-47.

Gretzel, U., Sigala, M., Xiang, Z., \& Koo, C. (2015). Smart tourism: foundations and developments. Electronic Markets, 25(3), 179-188. DOI: 10.1007/s12525-015-0196-8.

Gretzel, U., Werthner, H., Koo, C., \& Lamsfus, C. (2015). Conceptual foundations for understanding smart tourism ecosystems. Computers in Human Behavior, 50, 558-563. DOI: 10.1016/j. chb.2015.03.043.

Hedlund, J. (2012). Smart city 2020: Technology and society in the modern city.

Huang, C. D., Goo, J., Nam, K., \& Yoo, C. W. (2017). Smart tourism technologies in travel planning: The role of exploration and exploitation. Information and Management, 54(6), 757-770.

DOI: $10.1016 /$ j.im.2016.11.010.

Internal material of MVI, Inc. (2018). 
Ivars-Baidal, J. A., Celdrán-Bernabeu, M. A., Mazón, J. N., \& Perles-Ivars, Á. F. (2017). Smart destinations and the evolution of ICTs: a new scenario for destination management? Current Issues in Tourism, 3500(October), 1-20. DOI: 10.1080/13683500.2017.1388771.

Mills, A., Durepos, G., \& Wiebe, E. (2010). Encyclopedia of Case Study Research. 2455 Teller Road, Thousand Oaks California 91320 United States : SAGE Publications, Inc. DOI: $10.4135 / 9781412957397$.

Moore, J., F. (1993). Predators and Prey: A New Ecology of Competition. Harvard Business Review, 71 (May-June), 75-86.

Neuhofer, B., Buhalis, D., \& Ladkin, A. (2012). Conceptualising technology enhanced destination experiences. Journal of Destination Marketing and Management, 1(1-2), 36-46. DOI: 10.1016/j. jdmm.2012.08.001.

Perfetto, M. C., \& Vargas-Sánchez, A. (2018). Towards a Smart Tourism Business Ecosystem based on Industrial Heritage: research perspectives from the mining region of Rio Tinto, Spain. Journal of Heritage Tourism, 1-22. DOI: 10.1080/1743873X.2018.1445258.

Tourism support act. (2010). Act No. 91/2010 Coll. on the promotion of tourism, as amended. Slovak Republic.

Tran, H. M., Huertas, A., \& Moreno, A. (2017). (SA) ${ }^{6}$ : A new framework for the analysis of smart tourism destinations. A comparative case study of two Spanish destinations. In Congresos-Seminario Destinos Turisticos Inteligentes 2017-Libro de Actas (pp. 190-214). DOI: 10.14198/DestinosTuristicos-Inteligentes.2017.09.

Vecchio, P. Del, Mele, G., Ndou, V., \& Secundo, G. (2017). Creating value from Social Big Data: Implications for Smart Tourism Destinations. Information Processing and Management, (October), 1-14. DOI: 10.1016/j.ipm.2017.10.006.

Washburn, D., Sindhu, U., Balaouras, S., Dines, R. A., Hayes, N. M., \& Nelson, L. E. (2010). Helping CIOs Understand 'Smart City' Initiatives: Defining the Smart City, Its Drivers, and the Role of the CIO. Cambridge, MA.

Werthner, H., \& Klein, S. (1999). Information technology and tourism : a challenging relationship. Wien: Springer.

Xiang, Z., \& Fesenmaier, D. R. (2017). Big Data Analytics, Tourism Design and Smart Tourism. In Z. Xiang \& D. R., Fesenmaier (Eds.), Analytics in Smart Tourism Design, Concepts and Methods (pp. 299-307). Cham: Springer International Publishing Switzerland. DOI: 10.1007/978-3-31944263-1.

Xiang, Z., Tussyadiah, I., \& Buhalis, D. (2015). Smart destinations: Foundations, analytics, and applications. Journal of Destination Marketing and Management, 4(3), 143-144. DOI: 10.1016/j. jdmm.2015.07.001.

Zelenka, J. (2012). Informační a komunikační technologie - perpetuum mobile cestovního ruchu (Information and Communication Technologies - Perpetual Motion of Tourism). Czech Journal of Tourism, 1(1), 5-17.

Zhang, L., Li, N., \& Liu, M. (2012). On the Basic Concept of Smarter Tourism and Its Theoretical System. Tourism Tribune, 27(5), 66-73.

Zhu, W., Zhang, L., \& Li, N. (2014). Challenges, Function Changing of Government and Enterprises in Chinese Smart Tourism. Enter 2014. 